\title{
Auditorium Acoustics
}

\author{
Raf Orlowski
}

Ramboll Acoustics, Cambridge CB2 1NL, UK; Raf.Orlowski@ramboll.co.uk

Received: 22 August 2019; Accepted: 23 August 2019; Published: 28 August 2019

This Special Issue on the subject of Auditorium Acoustics follows an international conference which was held at the new Elbphilharmonie in Hamburg in October, 2018. Around 200 delegates from all parts of the world attended the conference and 83 papers were presented on a broad range of topics in auditorium acoustics. The success of the conference is that it brought together all the current thinking on auditorium acoustics from around the world. To record this success, a number of the papers, which are considered to be of particular importance, have been assembled in this Special Issue "Auditorium Acoustics" in Acoustics.

The conference also included attendance at an orchestral rehearsal in the new concert hall, which led to an interesting debate about the relative merits of the "shoebox" and "vineyard terrace" types of hall [1,2].

Two of the papers in this special issue provide an excellent historical background which describes the major pioneering work in auditorium acoustics in the second half of the twentieth century such as that carried out by Beranek, Marshall [3], and Barron [4]. Beranek's thinking was presented by his personal friend Jerry Hyde, whilst research work in the 1960's including that of Marshall and Barron was written by Barron himself.

The remaining papers, which include ideas on dynamic spatial responsiveness in concert halls [5], subjective rating of acoustic conditions in a symphony orchestra [6], and a practical comparison between "shoebox" and "vineyard terrace" halls are excellently bookended in the paper by Tapio Lokki and Jukka Patynen entitled "Architectural features that make Music Bloom inn Concert Halls" [2].

Conflicts of Interest: The authors declare no conflict of interest.

\section{References}

1. Harris, R. Advantages and Disadvantages of Surround-Type Concert Halls. Acoustics 2019, 1, 582-589. [CrossRef]

2. Lokki, T.; Pätynen, J. Architectural Features That Make Music Bloom in Concert Halls. Acoustics 2019, 1, 439-449. [CrossRef]

3. Hyde, J.R. Discussion of the Relation between Initial Time Delay Gap (ITDG) and Acoustical Intimacy: Leo Beranek's Final Thoughts on the Subject, Documented. Acoustics 2019, 1, 561-569. [CrossRef]

4. Barron, M. Developments in Concert Hall Acoustics in the 1960s: Theory and Practice. Acoustics 2019, 1, 538-548. [CrossRef]

5. Green, E.; Kahle, E. Dynamic Spatial Responsiveness in Concert Halls. Acoustics 2019, 1, 549-560. [CrossRef]

6. Skålevik, M. Simulations and Subjective Rating of Acoustic Conditions in a Symphony Orchestra-A Case Study. Acoustics 2019, 1, 570-581. [CrossRef]

(C) 2019 by the author. Licensee MDPI, Basel, Switzerland. This article is an open access article distributed under the terms and conditions of the Creative Commons Attribution (CC BY) license (http://creativecommons.org/licenses/by/4.0/). 